Ifomesteads Umeovermalole 


\section{NUNBER THREE}

$$
\begin{aligned}
& \text { Jack and Doris Smothers Series } \\
& \text { in Jexas Jistory, Dife, and Culture }
\end{aligned}
$$




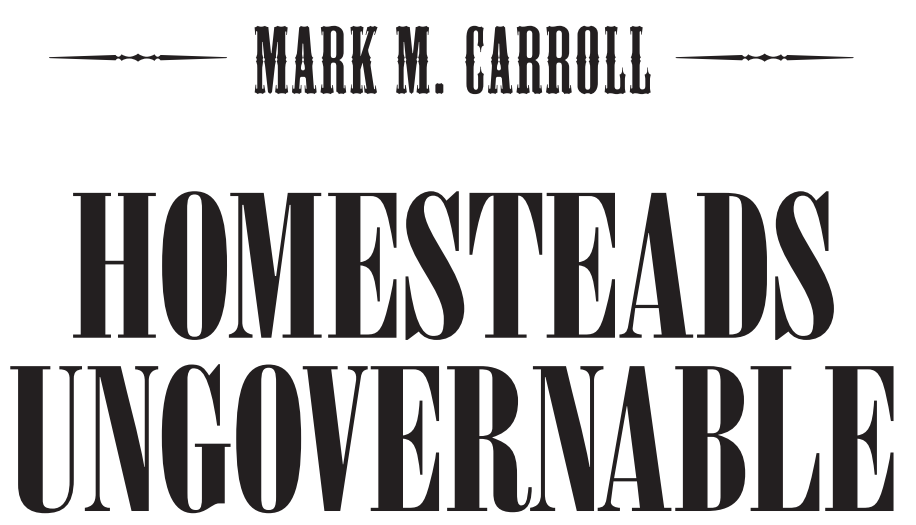

Families, Sex, Race

$$
\text { the } \stackrel{\stackrel{\text { AND }}{\sim}}{\text { Saw in }}
$$

Frontier Jexas,

$1823-1860$

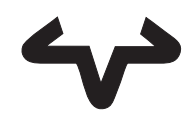

WNIVRSITY OP PEXAS PARSS, ALSPII 
Publication of this work was made possible in part by support from the J. E. Smothers, Sr., Memorial Foundation and the National Endowment for the Humanities.

COPYRIGHT (C) 200 I BY THE UNIVERSITY OF TEXAS PRESS

All rights reserved

Printed in the United States of America

First edition, 200I

Requests for permission to reproduce material from this work should be sent to:

$$
\begin{gathered}
\text { Permissions } \\
\text { University of Texas Press } \\
\text { P.O. Box 7819 } \\
\text { Austin, TX 78713-7819. }
\end{gathered}
$$

(@) The paper used in this book meets the minimum requirements of ANSI/NISO Z39.48-1992 (RI997) (Permanence of Paper).

\section{LIBRARY OF CONGRESS CATALOGING-IN-PUBLICATION DATA}

\section{Carroll, Mark M. (Mark McNeese)}

Homesteads ungovernable : families, sex, race, and the law in frontier Texas, I823-I86o / by Mark M. Carroll.—ist. ed.

p. $\mathrm{cm}$.

Includes bibliographical references and index.

ISBN 0-292-71227-8 (cloth : alk. paper)—ISBN 0-292-71228-6 (pbk. : alk. paper)

I. Family-Texas-History-19th century. 2. Sex role-TexasHistory - I9th century. 3. Domestic relations-Texas-HistoryIgth century. 4. Frontier and pioneer life-Texas-History-19th century. 5. Texas-Race relations. 6. Texas-Social life and customs. I. Title.

HQ536.I5.T4 C37 2OOI

$306.85^{\prime} 09764^{\prime} 09034-\mathrm{dc} 21$

$00-04435 \mathrm{I}$ 


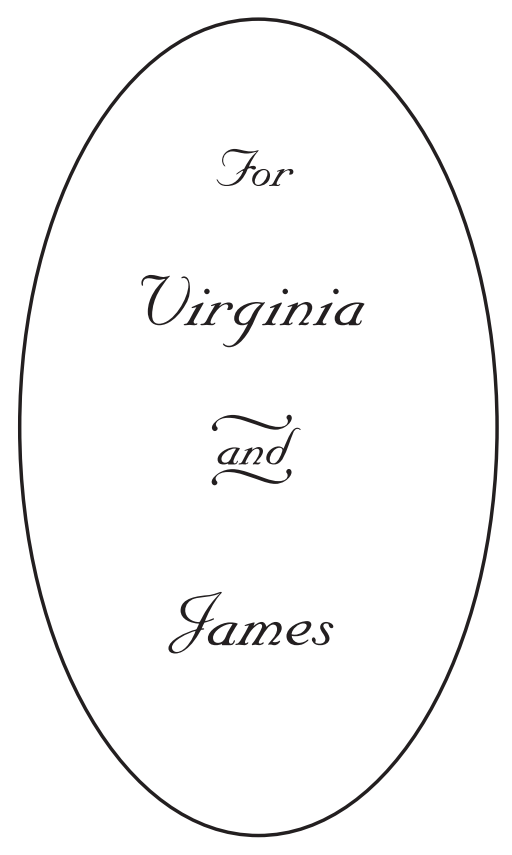


THIS PAGE INTENTIONALLY LEFT BLANK 